\title{
In closing: Le cabinet du docteur Ferron, a film by Jean-Daniel Lafond
}

$\mathrm{T}$ The full-day Jacques Ferron symposium ended in Theatre B in the Dalhousie Faculty of Medicine with an evening screening of Le cabinet du docteur Ferron, an 82 minute National Film Board documentary on Dr. Ferron's life and work. As its title indicates, the film places the doctor's office at the centre of his universe.

A review of Le cabinet du docteur Ferron by Dalhousie professor of psychiatry Dr. Normand Carrey, who was in the audience when the film was shown on the night of April 25, was subsequently published in the August 152006 issue of the Canadian Medical Association Journal ("Jacques Ferron: transcending solitudes," CMAJ 175:4, p. 389-390 ). This review is just one of the many echoes and reverberations of the Dalhousie symposium, and in particular of that final screening which opened up for the first time to Dr. Carrey, and to so many others, the world of Dr. Jacques Ferron.

In closing, The Dalhousie Medical Journal is pleased to be able to include below a short excerpt from the film-maker's own reflections on his film. Unable to be present in Halifax to discuss his film that night with the audience of over sixty people, film-maker JeanDaniel Lafond was kind enough to send the organizers a text in which he comments on the genesis of his film and reflects on the concept of roman-documentaire, or "documentary novel." It is a genre which draws on the conventions of both cinema and literature, seeking to document reality and at the same time to reveal what Ferron himself called "la réalité [qui] se dissimule derrière la réalité" - in other words, the hidden reality that lies beyond.

\section{The Editors}

Betty Bednarski and Derek Roberts

\section{Le cabinet du docteur Ferron: roman documentaire (extraits)}

His Excellency, Jean-Daniel Lafond

Alors comment peut-on être à la fois romanesque et documentaire?

Cela relève évidemment de plusieurs choix, artistiques, esthétiques et même philosophiques, et cela conduit aussi à des modes de réalisation et des écritures spécifiques.

Pour moi, scénariser un "roman documentaire" une fois ce cadre posé, c'est tracer une ligne dramatique, esquisser des mouvements de caméra, imaginer des lumières, des saisons, nommer les lieux... Bien sûr, c'est aussi nommer les acteurs et les témoins...

En somme le scénario est un miroir aux alouettes qui permet de tendre un piège à la réalité pour tenter de lui faire rendre gorge, pour produire une image du réel. Au mieux du processus, la transmutation révèle le sens profond, le sens caché du réel: le merveilleux.

Une phrase de Jacques Ferron résume ce principe du merveilleux, que j'avais déjà rencontré chez les écrivains d'Amérique latine et de la Caraïbe, en particulier chez Garcia Marquez ou René Depestre: "La réalité se dissimule derrière la réalité."

Quand on imagine le portrait d'un écrivain disparu depuis 18 ans, que l'on a croisé un jour, dont l'œuvre est fondée en majeure partie sur son expérience de vie, réelle ou rêvée, et sur l'imaginaire d'une société (et non pas sur une société imaginaire)... un de mes questionnements, c'est de savoir comment conduire le spectateur à entrer de plain-pied dans un monde apparemment aussi complexe, par la voie la plus simple et la plus naturelle.

Là se croise l'urgence de faire ce film avec cet homme et son cuvre avec mon désir de partager 
cette aventure de la connaissance et de la découverte avec le spectateur, cette sorte de voyageur sans bagage, qui entre dans le voyage sans le regard ébloui du cinéaste...

Je m'adresse à des êtres singuliers, pour raconter un destin singulier et j'ai, en conséquence, une écriture singulière, unique au propos et à mon rapport à ce propos.

...

Dans Le cabinet du Dr Ferron, le romanesque, l'écriture de Ferron en l'occurrence, se mêle à la voix des témoins, s'incarne dans le corps de l'acteur, inspire la caméra, provoque la nature du montage et influe sur le choix de l'écriture cinématographique. Mais ensuite la caméra provoque et capte aussi la présence des témoins qui reprennent place dans le cabinet du médecin-écrivain reconstitué fidèlement en studio, avec son bureau et ses armoires retrouvées, les manuscrits épars sur la table, et le cendrier débordant de cigarettes. Le lieu a une fonction très forte de révélateur, ravive par un étonnant effet de réalité, le temps retrouvé, et révèle en creux la présence de l'écrivain disparu. La caméra qui a pris sa place derrière le bureau se mue en regard et saisit tout ce que l'écrit en amont ne pouvait qu'espérer voir un jour. À cela s'ajoute l'imprévisible de la situation qui se vit ici et maintenant. Ce que capte la caméra n'est plus de l'ordre du possible mais de la singularité.

L'écriture avant le tournage permet de se mettre au clair avec soi-même, avec son point de vue en tentant de le partager et de convaincre. La caméra va partir de cette hypothèse pour traquer ce qui se passe. Mais ce qui se passe échappe souvent à la logique de l'histoire que l'on voulait raconter. La caméra n'est pas dans le présent, elle est dans l'actuel, dans ce qui est en train d'être, ce qui est en train d'advenir ici et maintenant.

Avant de filmer, avant l'intervention de la caméra, l'écriture est une tentative de légitimer le rapport au sujet, elle est une espèce d'engagement qui lie le cinéaste à l'action de filmer un lieu, des personnages, ce qui va se passer.

Pourquoi avoir fait un film en 2002 à partir de la vie et de l'œuvre de Jacques Ferron, écrivain et médecin, mort en 1985? L'écriture fouille une intention, expose un vouloir dire, défend un point de vue, justifie la raison du voyage. L'écriture préalable, le scénario, tente l'impossible: dire ce que sera ce film en croyant échapper à l'improbable, pour dire l'essentiel comme si le réel n'avait pas plus d'un tour dans son sac.

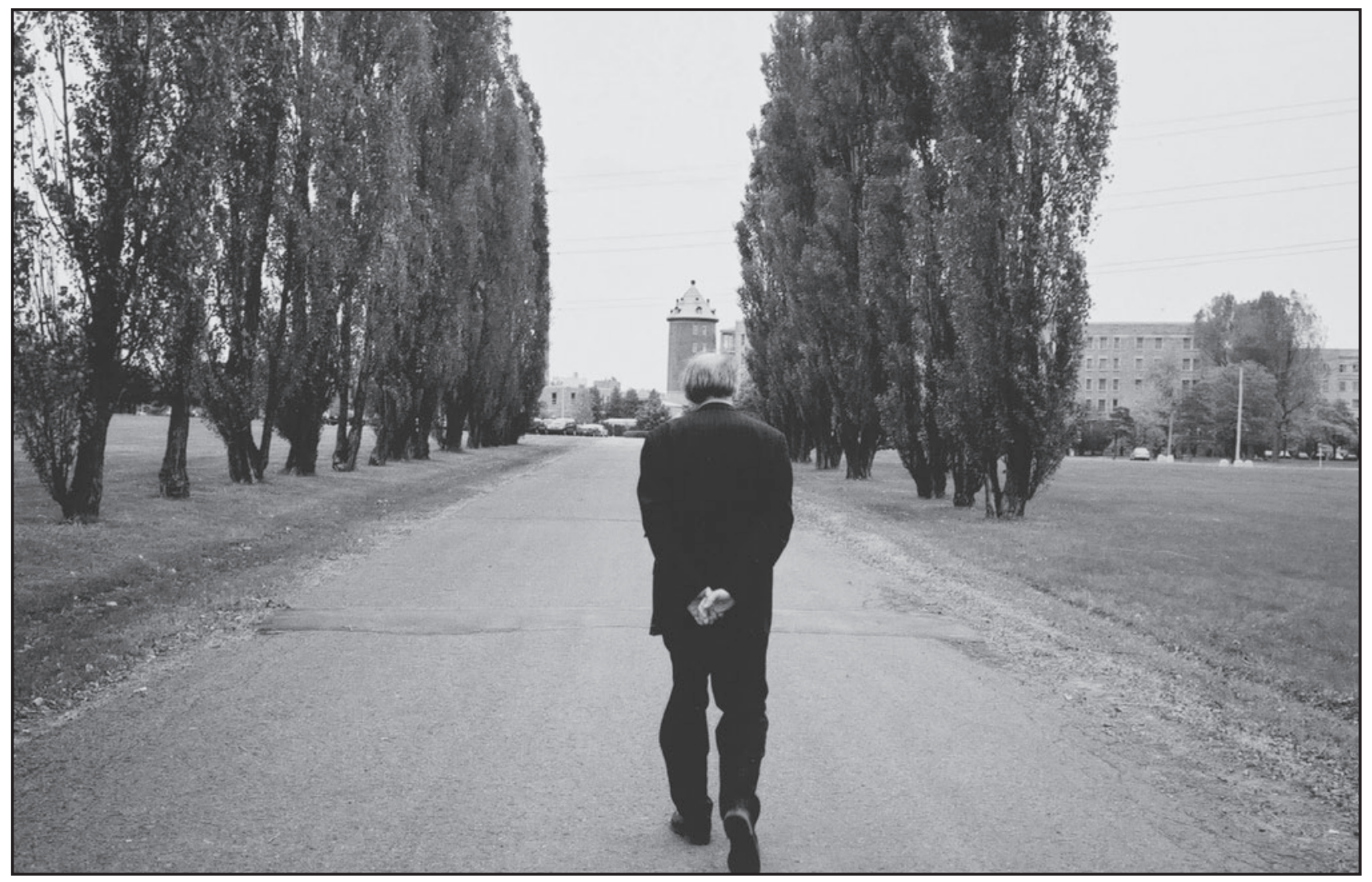




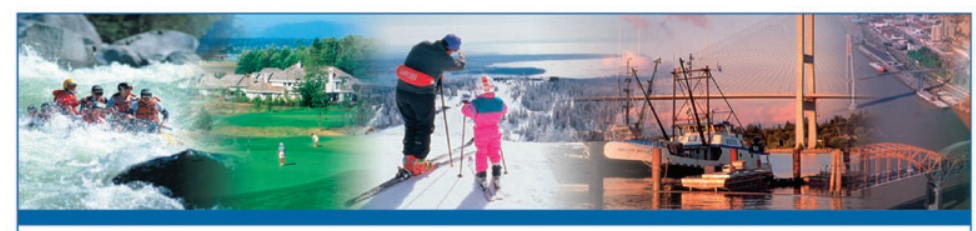

\section{imagine}

\section{British Columbia only happens once in the world!}

We're Fraser Health, and we believe a workplace where research, dedication and innovation in practice is admired, and lifelong learning is encouraged, will help us achieve our vision of Better health, Best in health care for the 1.5 million people we serve. Why settle for less?

In this corner of British Columbia, our mild climate keeps the doors wide open year-round for recreational adventures such as golfing, skiing, hiking, rock climbing, fishing and boating - and you can choose between a charming rural setting or everything urban in our vibrant city centers. Here you can balance your work and lifestyle in a community that meets your needs.

For a detailed description of our Practice opportunities, please visit our website at: www.fraserhealth.ca. To apply, please submit your CV by e-mail to recruitment@fraserhealth.ca or by fax at (604) 953-5135.

Imagine the possibilities....then live them!

fraserhealth

Befter health. Best in health care.

www.fraserhealth.ca

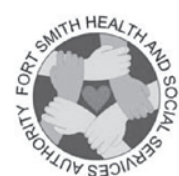

Fort Smith, the garden capital of the Northwest Territories is located on the banks of the Slave River just one mile from the Alberta/NWT border. This community provides a variety of social, recreational and cultural activities for it's 3,000 residents, and is surrounded by a vast natural setting ideal for outdoor enthusiasts. Here you can spend the long summer days camping, hiking and kayaking along the many rivers, rapids and lakes in the area, or tending to your garden. Winter days can be filled with snowmobiling, cross-country skiing, snowshoeing and a whole lot more.

Our family physicians and health professionals provide health care services to patients in a twenty-two bed hospital, and the community.

$>$ Family Physicians

$>$ Physiotherapist, Occupation Therapist and Speech Language

$>$ Registered Nurses

> Public Health \& Home Care Nurses

$>$ Dialysis nurses

$>$ Licensed Practical Nurses

$>$ Nurse Practitioners

$>$ Midwives

Contact Dana Rasiah, Chief Executive Officer, Fort Smith Health \& Social Services Authority, P.O. Box 1080, Fort Smith, NT, X0E-0P0, Phone: 867-872-6257, Fax: 867-872-6291, e-mail: dana_rasiah@gov.nt.ca

\section{There's a lot more to lífe in Nova scotía.}

\section{You've already decided to make your living caring for others. \\ Now you just have to choose where.}

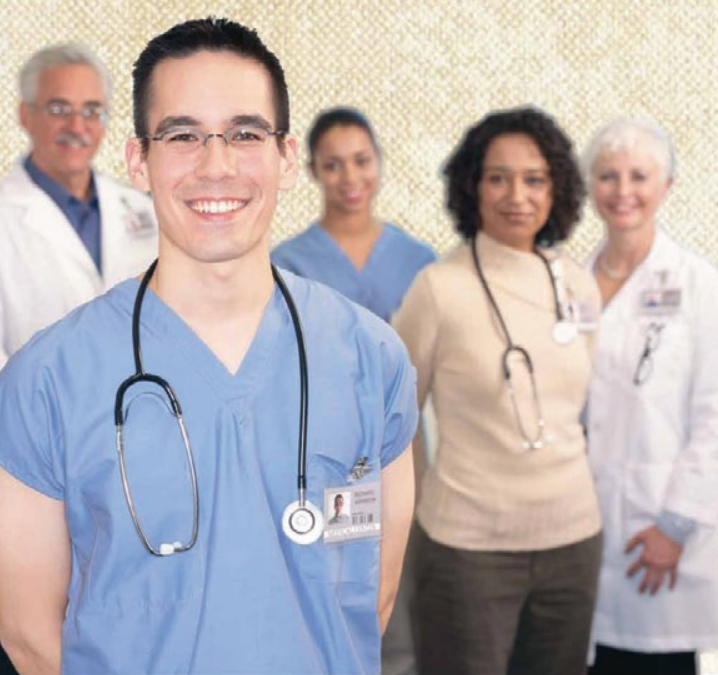

\section{Come to Capital Health, Nova Scotia}

Where patient care comes first - and is second to none.

Where you'll build a rewarding career with world-class health care colleagues.

Where academic and research opportunities abound at nationally recognized Dalhousie University.

Where the Atlantic Ocean is close enough for you to dip your toe... while on your lunch break.

Where you'll wonder what took you so long to get here.

To learn about the choices and opportunities at Capital Health, please contact:

Capital Health Tel: (902) 473-4313 Email: david.osmond@cdha.nshealth.ca or visit www.cdha.nshealth.ca 


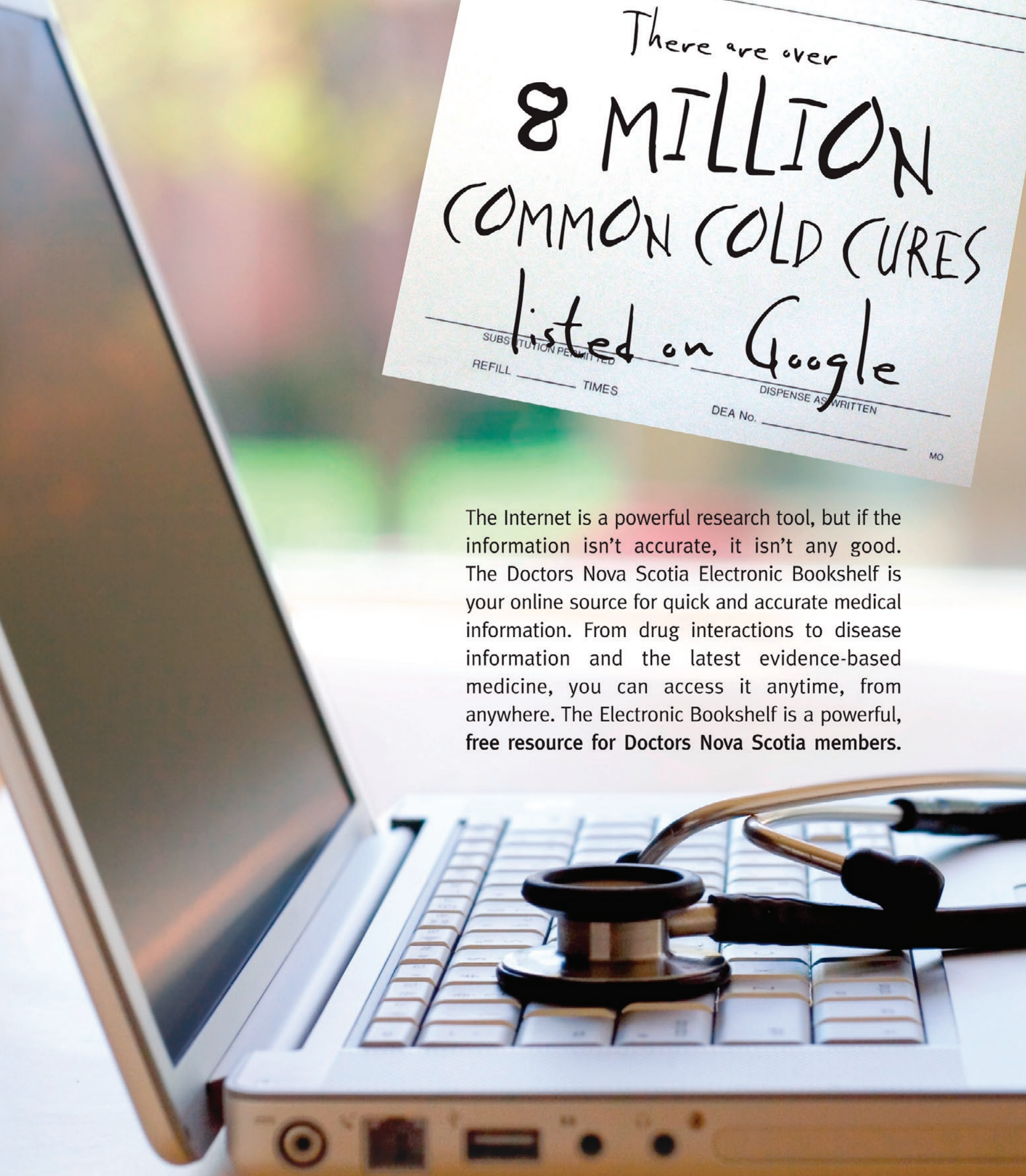

60 textbooks $\bullet 1,200$ journals $\bullet 12,000$ patient hand-outs $\bullet$ Toll-free support and full-time librarian service $\bullet \mathrm{CME}$ accredited workshops available throughout the province

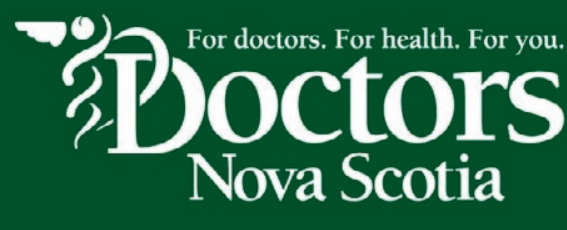

